\title{
Muş İlinde Bulunan Süt Sığırcılı̆̆ı İşletmelerinin Bazı Yapısal Özelliklerinin Crosstab Analiziyle Belirlenmesi
}

\author{
Galip BAKIR ${ }^{\mathscr{P}(D)}$, Mustafa KİBAR ${ }^{2}$ D \\ 1,Kahramanmaraş Sütçü İmam Üniversitesi, Ziraat Fakültesi, Zootekni Bölümü, Kahramanmaraş, ${ }^{2}$ Selçuk Üniversitesi, Ziraat Fakültesi, \\ Zootekni Bölümü, Konya \\ ${ }^{1}$ https://orcid.org/0000-0002-0816-227X, ${ }^{2}$ https://orcid.org/0000-0002-1895-019X \\ 凶: galipbakir@hotmail.com
}

\section{ÖZET}

$\mathrm{Bu}$ araştırmada, süt sığırcılı̆̆ı işletmelerinin bazı yapısal durumunu değerlendirmek amacıyla Muş İli ve 5 ilçesinde 346 işletme sahibiyle yüz yüze anket çalışması yapılmıştır. Buna göre, işletmecilerin ortalama yaşı 44.21 yıl, hayvancılık yaptığı süre 21.22 yıl, hanedeki birey sayısı 7.16 ve işletmede bulunan hayvan sayısı ortalama 37.54 baş olarak belirlenmiştir. İşletmecilerin eğitim durumu okuryazar olmayan \%9.1, ilkokul \%51.5, ortaokul \%24.6, lise \%13.5 ve üniversite \%1.5 şeklinde değişmektedir. Muş ilinin süt sı̆̆ırcılığı için uygun olmadığını bildiren işletmecilerin \%58.8'i neden olarak "yem־ot pahalı + mera az" sorununu belirtmişlerdir. İşletmelerde bulunan melez ve kültür ırklarının oranları sırasıyla \%38.4 ve \%7.5 şeklindedir. Melez Irklar içerisinde Simental (\%40.4) ve Simental-Esmer (\%30.5) melezleri en fazla bulunmaktadır. İşletmelerde damızlık temini kendi işletmesi (\%37.4), pazar (\%28.1) ve il dişı (\%4.1) ile bunların kombinasyonlarından oluşmaktadır. İl genelinde kültür ırkı oranı $\% 7.5$ iken, bu oran Hasköy ilçesinde \%41.2 ve Korkut'ta \%54.2 olarak bulunmuştur. İşletmedeki sorunlar, yemin pahalı olması, destek priminin az olması, kredi ve veteriner hizmeti şeklindedir. İsletmecilerin beklentileri destek primlerinin artırılması ve damızlık hayvan temininde yardım olarak belirlenmiştir.

\section{Araştırma Makalesi}

$\begin{array}{ll}\text { Makale Tarihçesi } \\ \text { Geliş Tarihi } & : 14.01 .2019 \\ \text { Kabul Tarihi } & : 09.03 .2019\end{array}$

\section{Anahtar Kelimeler}

Sığırcılık işletmeleri

Yapısal durum

Muş

Crosstabb analizi

Determination of Some Structural Characteristics of Dairy Cattle Breeding Enterprises via Crosstab Analysis in Muş Province

\section{ABSTRACT}

This research was conducted to determine the structural status of 346 dairy farms located in Muş province and its 5 districts. Accordingly, the average age of the farmers, number of years as a livestock farmer, number of family members and number of animals in the farm were 44.21, 21.22 years, 7.16 and 37.54 heads, respectively. The educational status of the farmers varied from nonliterate $(9.1 \%)$, primary school $(51.5 \%)$, middle school $(24.6 \%)$, and high school (13.5\%) to university (1.5\%). Overall, $23.7 \%$ of the farmers reported that Mus was not suitable for dairy cattle due to the problem of "feed-herb expense + limited pasture area" (58.8\%). The ratios of crosbred and cultivated breeds in the farms were $38.4 \%$ and $7.5 \%$, respectively. Simental (40.4\%) and Simental-Brown Swiss (30.5\%) crosbred were the most intense crossbred. In these enterprises, the breeding base consisted of its own (37.4\%), market (28.1\%) and nonprovince $(4.1 \%)$ and their combinations. While the rate of culturebreed throughout the province was $7.5 \%$; this rate increased to $41.2 \%$ in Hasköy and $54.2 \%$ in Korkut districts. Problems encountered in enterprises were mainly due to feed expense, followed by credit and veterinary services, while expectancy was determined mainly as subsidies and breeding animals.

\section{Research Article}

Article History

Received

: 14.01 .2019

Accepted

: 09.03.2019

Keywords

Cattle Breeding Enterprises

Structural Condition

Muş

Crosstabb analysis

To Cite: Bakır G, Kibar M 2019. Muş İlinde Bulunan Süt Sığırcılığı İşletmelerinin Bazı Yapısal Özelliklerinin Crostabb Analiziyle Belirlenmesi. KSÜ Tarım ve Doğa Derg 22(4): 609-619. DOI: 10.18016/ksutarimdoga. vi. 455439 


\section{GIRISŞ}

Süt, yeterli ve dengeli beslenme, çocukların büyüyüp gelişmesi gibi temel ihtiyaçlar bakımından önemli bir gıda maddesidir. Ayrıca süt ve süt ürünlerinin tüketim seviyesi ülkelerin gelişmişlik düzeyinin bir göstergesi olarak kabul edilmektedir. Süt sığırcılığı Türkiye'de önemli bir hayvancılık sektörü olup ülkenin kalkınmasına katkı sağlamaktadır. Tüm sektörlerde olduğu gibi süt sığırcılığı yapan işletmelerde de minimum masraf ile maksimum verimi alabilmek temel hedeftir. Bu nedenle Türkiye'de bulunan süt işletmelerinin mevcut durumlarının araştırılmass; sorunların giderilerek masrafların azaltılması ve bununla birlikte verimin artırılması açısından önemlidir (Boz, 2013).

Muş ilinde tarımsal faaliyetlere mevsim sınırlayıcı etken olurken, temel ekonomik sektörler içerisinde hayvancılık önemli bir yer tutmaktadır. Çayır ve meraların fazla olması sığırcılık için önemli bir alan açmaktadır. Muş il genelinde 126.540 baş melez, 104.698 baş yerli, 68.280 baş kültür ve 6.990 baş manda bulunmaktadır. Büyükbaş hayvan dağılımı içerisinde kültür ırklarının oranı Muş ili ve Türkiye'de sırasıyla \%22.28 ve \%48.46 şeklindedir. Buna göre, Muş genelinde kültür ırklarının hala yeteri kadar yaygınlaşmadığı anlaşılmaktadır. İnek başına yıllık ortalama süt verimi kültür ırklarında 3.5 ton, melez irklarda 2.7 ton, yerli irklarda 1.4 ton olup ortalama 2.33 ton olarak belirlenmiştir (Anonim, 2018).

İşletmelerin ve işletmecilerin sorunları, beklentileri, hayvan mevcudu ve ırkı, eğitim seviyesi, yaş, kayıt tutma, hayvancılık yaptığı süre vb. mevcut durumlarının belirlenmesi devletimiz tarafindan yapılacak olan politika ve stratejilerin daha isabetli olması bakımından önem arz etmektedir. Bu amaçla ülkemizin farklı bölgelerinde bu duruma katkıda bulunmak amacıyla birçok araştırmaların yapıldığı görülmektedir (Bakır, 2002; Kaygisız ve ark. 2008; Kaygısız ve Tümer 2009; Akkuş, 2009; Öztürk, 2009; Kaygisız ve ark., 2010; Tugay ve Bakır, 2010; Şeker ve ark., 2012; Tilki ve ark., 2013; Koçyiğit ve ark., 2015).

Şeker ve ark. (2012)'ı Muş ilinde 125 işletmede yapmış olduğu çalışmada sığır yetiştiriciliği yapan işletmelerin yapisal durumunu, işletme sahiplerinin özelliklerini ve sorunlarını değerlendirmişlerdir. Mevcut çalışma bu bakımdan değerlendirildiği zaman, Muş ilinde bulunan sığırcılık işletmelerinde 5 yıllık süreçte ne gibi değişiklerin yaşandığının izlenmesi bakımından ayrı bir önem taşımaktadır.

Bölgede işletmelerin yapısal özellikleri ile ilgili birçok araştırma yapılmıştır. $\mathrm{Bu}$ araştırmada incelenen özellikler ile ilgili olan araştırma sonuçları tarihsel sirasıyla verilmiştir. Erzurum ilinde Çoban ve ark. (2013) tarafından yapılan bir çalışmada, yetiştiricilerin \%83.9'unun buzağılama mevsiminin kış ve ilkbahar aylarında olmasını istedikleri bildirilmektedir.

Özyürek ve ark. (2014) Erzincan ili Çayırlı ilçesinde yaptıkları çalışmada, işletmecilerin \%64'ünün sağdıkları sütü kendilerinin değerlendirdiğini, işletmecilerin sadece \%10'unun sütü satmakta olduğunu, geri kalan işletmecilerin ise sütü sadece buzağıya verdiğini bildirmektedir. İşletmecilerin \%75.8'i günde iki defa sağım yaparken geri kalan işletmeciler günde bir kez sağım yapmaktadır. İşletmecilerin \%81'i elle sağım yaparken diğer işletmeciler seyyar sağım makinesi kullanmaktadır. İşletmecilerin \%93.3’ü sağım öncesi meme temizliği yapmakta geri kalanı ise sağım öncesi herhangi bir meme temizlik yapmadığını bildirmektedir.

Demir ve ark. (2014) Kars ilinde 162 işletmede yaptıkları bir çalışmada sütün pazarlanma yeri olarak; işletmelerin \%56.8'inin mandıralara sattığını, \%21.0'sinin ürettiği sütü kendinin pazarladığını, \%14.2'sinin ise fabrikalara verdiğini belirlemişlerdir

Aksoy ve ark. (2014) Erzurum ilinde yaptıkları çalışmada, yerli sığır oranının önemli ölçüde azaldığını ve üreticilerin \%88.7’lik kısmının sağımı elle yaptığını belirtmiştir. Birliğe üye olmayanlar içerisinde ise sağımı elle yapanların oranı \%50.0 düzeyindedir

Koçyiğit ve ark. (2016) Erzurum ili Hınıs ilçesinde yaptıkları çalışmada, işletmelerin \%85.0'inde sağım öncesi meme temizliğinin yapıldığı ve \%89.2'sinde elle sağımın tercih edildiği belirlenmiştir. Sığır yetiştiricilerinin \%73.0'ü sağımdan sonra sütü alüminyumdan yapılmış kaplarda bekletmektedirler. Yetiştiricilerin \%68.0'i ineklerinin sonbaharda doğurmasını istediklerini, \%61.0'i hayvan başına süt veriminin yaz mevsiminde daha çok olduğunu bildirmektedir.

Bakan ve Aydın (2016), Ağrı ilinde yaptıkları bir araştırmada, işletmelerde bölgenin hâkim kültür ırkının Esmer ırkı (\%67.28) olduğunu ve bunu yerli irklar (\%11.57), \%8.75 Simental ırkı ve melez irk (\%5.84) sığırların takip ettiğini bildirmektedir. İşletmecilerin üretilen sütün \%15.1'ini süt toplayıcılarına, \%2.8'ini mandıraya, \%82.1'ini diğer şekillerde (ev ihtiyacı, isteyene satış vs) değerlendirmekte olduğunu bildirmişlerdir.

Koçyiğit ve ark. (2017) Erzurum ili Narman ilçesinde yaptıkları çalışmada, işletmecilerin \%24.5'inin ineklerini 10 ay sağdıklarını ve sağım esnasında işletmecilerin \% 75.5 ' inin kesif yem verdiğini tespit etmiştir. Sağım öncesi meme temizliği yapmayan işletmelerin \%54.4 olduğu ve \%78.8 'inde elle sağım yapıldığı belirlenmiştir. Sı ğır yetiştiricilerinin \%68.6'sı sağımdan sonra sütü alüminyum kaplarda ahır dışında bekletirken, \%30.9'unun ahır ortamında beklettiği ve \%0.5'inin ise soğutma tankında depoladığı bildirilmektedir. Yetiştiricilerin \%52.2'si hayvan başına süt veriminin yaz mevsiminde daha yüksek olduğunu bildirmişlerdir. Araştırıcılar 
Narman ilçesindeki sığırcılık işletmelerinin sağım öncesi meme temizliği uygulama oranındaki düşüklüğe dikkat çekerek, bu uygulamanın en kısa sürede yükseltilmesi konusunda yetiştiricilerin alışkanlıklarını değiştirmesi ve bu amaçla eğitim çalışmalarında sağım öncesi meme temizliği ve hijyeni konusuna daha fazla önem verilmesi gerektiğini bildirmektedir.

$\mathrm{Bu}$ çalışma ile işletmecilerin yaşı, hayvancılık yaptığı süre, eğitim, hanedeki birey sayısı gibi demografik özelliklerin belirlenmesi yanında, işletme özelliği, damızlık temin şekli, ilin sığırcılık için uygunluğu, işletmelerde bulunan irklar, kayıt tutma, sorunlar, beklentiler gibi bir kısım yapısal özellikler incelenmiştir. Şeker ve ark. (2012) tarafindan sadece Muş il merkezindeki işletmeleri kapsayan çalışmada, incelenen özelliklere ait frekans değerleri verilirken, bu çalışma dahil merkezi yanında ilçeleri de çalışmaya dahil edilmiş ve incelenen özellikler il genelinin yanında mevkiye (ilçe) göre de sınıflandırılarak daha detaylı olarak araştırılmıştır.

\section{MATERYAL-METOT}

Araştırma materyalini, Muş ili merkez ve ilçelerinde (Malazgirt, Bulanık, Hasköy, Korkut ve Varto) bulunan büyükbaş hayvancılık işletmelerinde yüz yüze yapılan anket verileri oluşturmuştur. Araştırmada, büyükbaş hayvan varlığı bakımından ilçeleri temsil eden köyler, bölgede görev yapan veteriner hekimlerin görüşü alınarak belirlenmiştir. Muş yöresine kayıtlı büyükbaş hayvancılık işletmelerinden 2017 yılında anket yolu ile veriler toplanmıştır. Muş İl Tarım ve Orman Müdürlüğü kayıtlarından alınan toplam işletme sayısı dikkate alınarak, 346 (\%3.3) işletme şansa bağlı olarak belirlenmiştir. İşletme sayısının belirlenmesinde örnek hacminin en az \%3'ünün (Yamane, 2006) veya belirttiği örnek hacminin \%10'unun (Cochran, 1977) alınmasının yeterli olacağı ilkesi dikkate alınmıştır. Verilerin analizlerinde SPSS 21.0 paket programı kullanılarak, çapraz çizelgeler (crosstabs) oluşturulmuş, faktörlerin etkilerini belirlemek için ki-kare önemlilik testi (Düzgüneş ve ark., 1983) yapılmış ve bazı özelliklere ait ortalama frekans değerleri verilmiştir.

\section{BULGULAR ve TARTIŞMA}

İşletmecilerin yaş, hayvancılık yaptığı süre, hane halkı sayısı ve eğitim durumu gibi demografik durumları incelenmiştir. Frekans değerlerine göre, işletmecilerin yaşı 18-75 yılları arasında geniş bir dağılım gösterirken, ortalama $44.21 \mathrm{yll}$; hayvancılık yaptıkları süre ise 1-60 yıl aralığında değişim gösterirken, ortalama 21.22 yıl olarak tespit edilmiştir. İşletmelerde hane halkı sayısı ortalama 7.16 iken, 124 arasında değişim göstermektedir. İşletmecilerin eğitim seviyesi ilkokul (\%51.5), ortaokul (\%24.6), lise
(\%13.5) ve üniversite (\%1.5) ve okuryazar olmayan (\%9.1) şeklinde tespit edilmiştir.

İşletmelerde sığırcılık yapma sürelerinin 1-60 yıl arasında değişmesi ve ortalama 21.22 yıl olması ile işletmecilerin \%72.5’nin 10 yılın üzerinde deneyime sahip olması; işletmecilerin hayvancılığı sürdürülebilir kıldıklarının göstergesi olarak değerlendirilebilir. Sığırcılık ile uğraşma süreleri diğer araştırmalarda, Ağrı ilinde 24.3 yıl (Bakan ve Aydın, 2016), Erzincan'da 22.2 yıl (Özyürek ve ark., 2014), Iğdır'da 25.74 yıl (Şahin ve Gürsoy, 2016) olarak bildirilmektedir. Ayrıca, Türkiye'de sığırcılıkta en fazla deneyim süresine sahip işletmecilerin bulunduğu ilin Kars ili (31.1 ve 30.2 yll) olduğu bildirilmektedir (Erdoğan ve ark., 2004; Tilki ve ark., 2013).

İşletme başına düşen hayvan sayısı ortalama 37.54 baş, minimum 2 ve maksimum 303 baş olarak tespit edilmiştir. Hayvan mevcudunu bildiren toplam 340 işletmenin \%50'sinin 20 baş ve daha az, \%89.4'ünün 100 baş ve altında hayvana sahip olduğu; 100 baştan fazla hayvana sahip işletmelerin oranının ise sadece $\% 10.6$ olduğu tespit edilmiştir.

Bakan ve Aydın (2016) tarafindan yapılan araştırmada, Ağrı ilindeki işletmelerde sığır sayısı ortalama $19.9 \pm 2.5$ baş olarak bulunmuştur. Siralama yapıldığında işletmelerin \%32.0'si $11-15$ baş, \%25.5'i ise 21 baş ve üzeri, \%20.8'i 6-10 baş ve \%17.9'u 16-20 baş sığıra sahip oldukları bildirilmiştir. İşletme başına düşen sığır sayısı Kars'ta 23.4 baş (Erdoğan ve ark., 2004), Erzurum'da 18 baş (Çoban ve ark., 2013) ve Sivas ilinde 23.8 baş (Hozman ve Akçay, 2016) olarak bildirmektedir.

İlde bulunan hayvancılık işletmelerinin yapısını ayrıntılı incelemek için mevki bazlı çapraz çizelgeler oluşturulmuştur. Buna göre, 30 ve altı yaş grubunu oluşturan genç işletmeciler \%14.2 ile en düşük orana sahipken, 40 ve üzeri yaşa sahip olan işletmecilerin oranının \%59.4 olduğu tespit edilmiştir (Çizelge 1). İlçe bazında ise, en genç yetiştiricilerin \%33.3 oranıla Korkut ilçesinde, en yaşl grubu oluşturan yetiştiricilerin ise il merkezinde bulunduğu belirlenmiştir. 30 ve altı yaş grubunu oluşturan yetiştiricilerin \%74.5'inin 10 yıldan daha az hayvancılık yaptığı yani bu işletmecilerin hayvancılığa yeni başlamış oldukları tespit edilmiştir.

Yetiştiricilerin hayvancılık yaptığı süre, ilçeler arasında çok fazla değişkenlik göstermiştir. Buna göre, Malazgirt ve Hasköy ilçesinde bulunan yetiştiricilerin hayvancılık yaptıkları süre sırasıyla (\%45.9) $10 \leq$ yll ve $(\% 42.1) \quad 21-30$ yll olarak belirlenmiştir (Çizelge 1). Bakan ve Aydın (2016) Ağrı ilinde yapmış olduğu çalışmada işletmecilerin süt sığırcılığı ile uğraşma sürelerinin 11-20 yıl arasında yoğunlaştığını ve ortalama 24.3 yl olduğunu bildirmiştir. Özyürek ve ark. (2014) Erzincan'da işletmecilerin sığırcılık ile uğraşma sürelerini 22.2 yıl, 
Şahin ve Gürsoy (2016) Iğdır'da 25.74 yıl olarak belirtmiştir. Şeker ve ark. (2012) Muş ilinde yapmış olduğu çalışmada işletmecilerin sığırcılıkla uğraşma sürelerinin çoğunlukla 21 yıl ve üzeri süreden oluştuğunu tespit etmişlerdir.

İşletmelerde bulunan hane halkı sayısı ilçeler arasında önemli değişkenliğe sahip olup, 9 ve üzeri bireye sahip işletmelerin \%61.9'u Hasköy ilçesinde bulunurken, $4 \geq$ bireye sahip işletmelerin \%37.5'i
Korkut ilçesinde bulunmaktadır (Çizelge 2). İşletmecilerin yaş ve eğitim durumları mevki bazında incelendiğinde, genç işletmecilerin en az olduğu ilçeler Merkez ve Varto iken, en yaşlı işletmecilerin olduğu ilçeler ise Merkez ve Bulanık olmuştur. Okuryazar olmayan işletmecilerin en yoğun olduğu ilçe Merkez olup, Varto ilçesindeki işletmecilerin \%60.7'sinin eğitim durumunun ilkokul olması dikkat çekmiştir (Çizelge 2).

Çizelge 1. İşletmecilerin yaş ve hayvancılık yaptığı sürenin mevkiye göre dağılımı

\begin{tabular}{|c|c|c|c|c|c|c|c|c|c|c|c|}
\hline \multirow{2}{*}{ Mevki } & & \multicolumn{4}{|c|}{ Yas* } & \multirow{2}{*}{ Toplam } & \multicolumn{4}{|c|}{ Hayvancılık yaptığı süre** } & \multirow{2}{*}{ Toplam } \\
\hline & & $30 \geq$ & $31-40$ & $41-50$ & $51+$ & & $10 \geq$ & $11-20$ & $21-30$ & $31+$ & \\
\hline \multirow{2}{*}{ Merkez } & Adet & 4 & 11 & 20 & 19 & 54 & 5 & 18 & 19 & 12 & 54 \\
\hline & $\%$ & 7.4 & 20.4 & 37 & 35.2 & 100 & 9.3 & 33.3 & 35.2 & 22.2 & 100 \\
\hline \multirow{2}{*}{ Malazgirt } & Adet & 18 & 27 & 23 & 14 & 82 & 34 & 27 & 8 & 5 & 74 \\
\hline & $\%$ & 22 & 32.9 & 28 & 17.1 & 100 & 45.9 & 36.5 & 10.8 & 6.8 & 100 \\
\hline \multirow{2}{*}{ Bulanık } & Adet & 11 & 26 & 36 & 36 & 109 & 19 & 27 & 33 & 29 & 108 \\
\hline & $\%$ & 10.1 & 23.9 & 33 & 33 & 100 & 17.6 & 25 & 30.6 & 26.9 & 100 \\
\hline \multirow{2}{*}{ Hasköy } & Adet & 3 & 7 & 7 & 4 & 21 & 4 & 2 & 8 & 5 & 19 \\
\hline & $\%$ & 14.3 & 33.3 & 33.3 & 19 & 100 & 21.1 & 10.5 & 42.1 & 26.3 & 100 \\
\hline \multirow{2}{*}{ Korkut } & Adet & 8 & 7 & 3 & 6 & 24 & 12 & 6 & 3 & 3 & 24 \\
\hline & $\%$ & 33.3 & 29.2 & 12.5 & 25 & 100 & 50 & 25 & 12.5 & 12.5 & 100 \\
\hline \multirow{2}{*}{ Varto } & Adet & 5 & 13 & 19 & 18 & 55 & 18 & 19 & 16 & 3 & 56 \\
\hline & $\%$ & 9.1 & 23.6 & 34.5 & 32.7 & 100 & 32.1 & 33.9 & 28.6 & 5.4 & 100 \\
\hline \multirow{2}{*}{ Toplam } & Adet & 49 & 91 & 108 & 97 & 345 & 92 & 99 & 87 & 57 & $\overline{335}$ \\
\hline & $\%$ & 14.2 & 26.4 & 31.3 & 28.1 & 100 & 27.5 & 29.6 & 26 & 17 & 100 \\
\hline
\end{tabular}

Çizelge 2. İşletmelerdeki hane halkı sayısı ve eğitim durumunun mevkiye göre dağılımı

\begin{tabular}{|c|c|c|c|c|c|c|c|c|c|c|c|c|}
\hline \multirow{2}{*}{ Mevki } & & \multicolumn{4}{|c|}{ Hane halkı sayısı** } & \multirow[b]{2}{*}{ Toplam } & \multicolumn{5}{|c|}{ Ĕ̆itim durumu** } & \multirow[b]{2}{*}{ Toplam } \\
\hline & & $4 \geq$ & $5-6$ & $7-8$ & $9+$ & & $\begin{array}{c}\text { Okuryazar } \\
\text { değil }\end{array}$ & İlkokul & Ortaokul & Lise & Üniversite & \\
\hline \multirow{2}{*}{ Merkez } & Adet & 11 & 15 & 14 & 14 & 54 & 8 & 28 & 14 & 4 & 0 & 54 \\
\hline & $\%$ & 20.4 & 27.8 & 25.9 & 25.9 & 100 & 14.8 & 51.9 & 25.9 & 7.4 & 0 & 100 \\
\hline \multirow{2}{*}{ Malazgirt } & Adet & 10 & 34 & 27 & 10 & 81 & 4 & 34 & 21 & 23 & 0 & 82 \\
\hline & $\%$ & 12.3 & 42 & 33.3 & 12.3 & 100 & 4.9 & 41.5 & 25.6 & 28 & 0 & 100 \\
\hline \multirow{2}{*}{ Bulanık } & Adet & 22 & 29 & 25 & 33 & 109 & 11 & 60 & 22 & 9 & 3 & 105 \\
\hline & $\%$ & 20.2 & 26.6 & 22.9 & 30.3 & 100 & 10.5 & 57.1 & 21 & 8.6 & 2.9 & 100 \\
\hline \multirow{2}{*}{ Hasköy } & Adet & 0 & 2 & 6 & 13 & 21 & 1 & 11 & 6 & 2 & 1 & 21 \\
\hline & $\%$ & 0 & 9.5 & 28.6 & 61.9 & 100 & 4.8 & 52.4 & 28.6 & 9.5 & 4.8 & 100 \\
\hline \multirow{2}{*}{ Korkut } & Adet & 9 & 7 & 6 & 2 & 24 & 1 & 9 & 11 & 3 & 0 & 24 \\
\hline & $\%$ & 37.5 & 29.2 & 25 & 8.3 & 100 & 4.2 & 37.5 & 45.8 & 12.5 & 0 & 100 \\
\hline \multirow{2}{*}{ Varto } & Adet & 7 & 16 & 23 & 9 & 55 & 6 & 34 & 10 & 5 & 1 & 56 \\
\hline & $\%$ & 12.7 & 29.1 & 41.8 & 16.4 & 100 & 10.7 & 60.7 & 17.9 & 8.9 & 1.8 & 100 \\
\hline \multirow{2}{*}{ Toplam } & Adet & 59 & 103 & 101 & 81 & 344 & 31 & 176 & 84 & 46 & 5 & 342 \\
\hline & $\%$ & 17.2 & 29.9 & 29.4 & 23.5 & 100 & 9.1 & 51.5 & 24.6 & 13.5 & 1.5 & 100 \\
\hline
\end{tabular}

$* * \mathrm{p}<0.01$

Ağrı ilinde yapılan çalışmada işletmecilerin eğitim durumunun çoğunlukla ilköğretim mezunu ve okuryazar olduğu bildirilmiştir (Bakan ve Aydın, 2016). Köseman ve Şeker (2016) Malatya ilinde yapmış olduğu çalışmada, işletmecilerin \%33.7'sinin üniversite mezunu olduğunu bildirmiştir. Şeker ve ark. (2012) Muş ilinde yapmış olduğu çalışmada işletme sahiplerinin eğitim durumunu ilkokul mezunu (\%38.4) olarak belirlemiştir.
İşletmelerin hayvan sayısına bakıldığında, genel olarak işletmelerin \%50'si $21 \geq$ baştan az ve \%10.6'sı $101 \leq$ baş havyan varlığına sahiptir. Ayrıca, Merkezde bulunan işletmelerin çoğunluğu (\%75.9) 21 2 baştan az hayvan varlığına sahipken, $101 \leq$ baştan fazla hayvan varlığına sahip işletmelerin oranı ise diğer ilçelere göre en düşük (\%3.7) oranda bulunmaktadır. Büyük

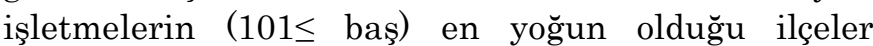
Bulanık, Malazgirt ve Korkut iken, büyük işletme 
olmayan ilçe ise Hasköy olarak tespit edilmiştir (Çizelge 3).

Ağrı ilinde yapılan çalışmada işletmelerin \%32'sinin 11-15 baş hayvana sahip olduğu ve ortalama işletme başına düşen hayvan sayısının 19.9 baş olduğu belirlenmiştir (Bakan ve Aydın, 2016). Erdoğan ve ark. (2004), Çoban ve ark. (2013) ve Hozman ve Akçay (2016) sirasiyla Kars, Erzurum ve Sivas illerinde yapmış oldukları çalışmalarında işletme başına düşen hayvan sayılarını 23.4 baş, 18 baş ve 23.8 baş olarak tespit etmiştir. Tugay ve Bakır (2008) Giresun ilinde yapmış olduğu çalışmada işletme başına ortalama 7.98 adet hayvanın düştüğünü belirtmiştir. Soysal ve Özder (2004), Türkiye'de işletme başına 3.9 adet hayvanın düştüğünü ve bu oranın hayvancılığı gelişmiş ülkelerin gerisinde olduğunu bildirmiştir. Ildız (1999) Tokat ilinde yapmış olduğu çalışmasında işletmelerin çoğunluğunun 6-10 baş arası hayvana sahip olduğunu bildirmiştir.

İşletmelerin damızlık temin şekli en fazla kendi işletmesi (\%37.4) iken, bunu \%28.1 oranıla pazar izlemektedir (Çizelge 3). İlçe bazında bakıldığında, Merkez (\%61.1) ve Hasköy'de (\%57.1) bulunan işletmeciler damızlık ihtiyacinı sırasıyla \%61.1 ve \%57.1 oranlarıyla kendi işletmesinden temin ederken, Korkut ilçesinde bu oran \%12.5 olarak bulunmuştur. Korkut ilçesinde damızlık temini hem işletmeden hem de pazardan (\%37.5) sağlanmaktadır. Bulanık'ta bulunan işletmelerin damızlık ihtiyacını daha çok (\%40.2) pazardan temin ettiği tespit edilmiştir.

Cizelge 3. Hayvan sayısı ve damızlık temin şeklinin mevkiye göre dağılımı

\section{Hayvan sayıs **}

\begin{tabular}{|c|c|c|c|c|c|c|}
\hline Mevki & & $\stackrel{\wedge}{\stackrel{1}{\Delta}}$ & $\begin{array}{l}0 \\
10 \\
1 \\
\text { ลे } \\
\end{array}$ & $\begin{array}{l}8 \\
8 \\
1 \\
11 \\
10\end{array}$ & $\stackrel{+}{+}$ & 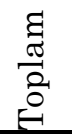 \\
\hline \multirow{3}{*}{ Merkez } & Adet & 41 & 10 & 1 & 2 & 54 \\
\hline & $\%$ & 75.9 & 18.5 & 1.9 & 3.7 & 100 \\
\hline & Adet & 41 & 24 & 5 & 10 & 80 \\
\hline \multirow[t]{2}{*}{ Malazgirt } & $\%$ & 51.2 & 30 & 6.2 & 12.5 & 100 \\
\hline & Adet & 35 & 44 & 14 & 15 & 108 \\
\hline \multirow[t]{2}{*}{ Bulanık } & $\%$ & 32.4 & 40.7 & 13 & 13.9 & 100 \\
\hline & Adet & 11 & 5 & 2 & 0 & 18 \\
\hline \multirow[t]{2}{*}{ Hasköy } & $\%$ & 61.1 & 27.8 & 11.1 & 0 & 100 \\
\hline & Adet & 14 & 6 & 1 & 3 & 24 \\
\hline \multirow[t]{2}{*}{ Korkut } & $\%$ & 58.3 & 25 & 4.2 & 12.5 & 100 \\
\hline & Adet & 28 & 17 & 5 & 6 & 56 \\
\hline \multirow[t]{2}{*}{ Varto } & $\%$ & 50 & 30.4 & 8.9 & 10.7 & 100 \\
\hline & Adet & 170 & 106 & 28 & 36 & 340 \\
\hline Toplam & $\%$ & 50 & 31.2 & 8.2 & 10.6 & 100 \\
\hline
\end{tabular}

İşletmelerin geneli Türkvet sistemine kayıtlı olup, ilçe bazında ise en fazla kayıtlı işletmeler Merkez ilçede bulunurken, en az kayıtlı işletmeler ise Malazgirt ilçesinde bulunmaktadır (Çizelge 4). İşletmelerin \% 56.8'inde kayıt tutulmaktadır. İlçeler arasında en fazla kayıt tutulan işletmelerin Korkut ilçesinde olmasının bu ilçedeki işletmelerin tamamının süt tipinde olmasından kaynaklandığı düşünülmektedir (Çizelge 4). Erzurum İli Narman İlçesi'nde yapılan bir araştırmada sığırcılık işletmelerinin \%13.5'inde hayvanlara ait bireysel kayitların tutulduğu saptanmıştır. Yetiştiricilerin eğitim durumu ve deneyim sürelerinin kayıt tutma alışkanlığını etkilemediği tespit edilmiş ve yetiştiricilerin genelde kayıt tutma eğiliminde olmadığı bildirilmiştir (Diler ve ark., 2017).

Yapılan diğer çalışmalarda ise kayıt tutma oranlarını Ildız (1999) \%24.4; Kaygisız ve ark. (2008) \%37; Önal ve Özder (2008) \%98.2; Çoban ve ark. (2013) \%13.3;
Damızlık temin sekli**

\begin{tabular}{|c|c|c|c|c|c|c|}
\hline 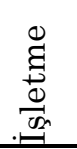 & 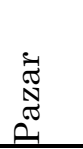 & $\begin{array}{l}\vec{\infty} \\
\vec{\sigma} \\
.\end{array}$ & 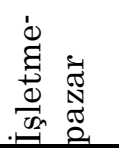 & 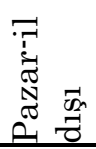 & 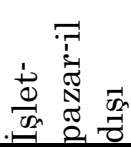 & 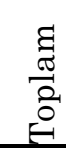 \\
\hline 33 & 16 & 3 & 0 & 1 & 1 & 54 \\
\hline 61.1 & 29.6 & 5.6 & 0 & 1.9 & 1.9 & 100 \\
\hline 40 & 20 & 3 & 3 & 1 & 14 & 81 \\
\hline 49.4 & 24.7 & 3.7 & 3.7 & 1.2 & 17.3 & 100 \\
\hline 16 & 43 & 3 & 15 & 13 & 17 & 107 \\
\hline 15.0 & 40.2 & 2.8 & 14 & 12.1 & 15.9 & 100 \\
\hline 12 & 6 & 1 & 0 & 2 & 0 & 21 \\
\hline 57.1 & 28.6 & 4.8 & 0 & 9.5 & 0 & 100 \\
\hline 3 & 4 & 0 & 9 & 2 & 6 & 24 \\
\hline 12.5 & 16.7 & 0 & 37.5 & 8.3 & 25 & 100 \\
\hline 24 & 7 & 4 & 10 & 3 & 7 & 55 \\
\hline 43.6 & 12.7 & 7.3 & 18.2 & 5.5 & 12.7 & 100 \\
\hline 128 & 96 & 14 & 37 & 22 & 45 & 342 \\
\hline 37.4 & 28.1 & 4.1 & 10.8 & 6.4 & 13.2 & 100 \\
\hline
\end{tabular}

Özyürek ve ark. (2014) \%48; Koçyiğit ve ark. (2015) \%26; Bakan ve Aydın (2016) \%81.1 ve Savaş ve Yenice (2016) \%8.1 olarak bildirmişlerdir.

İşletmelerde düzenli bir şekilde kayıt tutmak sadece yetiştiriciye değil, oluşturacağ $\breve{g}_{1}$ katma değer ile ülke ekonomisine de katkı sağlayacaktır. Özellikle süt sığırcılığı işletmelerinde pedigri, döl verimi, süt verimi, somatik hücre sayısı, vücut kondüsyon skoru ve işletme muhasebesi gibi kayıtların tutulması verimliliğin, karlılığın ve işletmenin geleceği konusunda doğru ve isabetli karar verme açısından çok önemlidir. Bu konuda yetiştiricilerin daha titiz davranması gerekmektedir (Diler ve ark., 2017).

Genel olarak işletmelerin \%51.4'ü kombine ve \%48.6'sı süt tipindedir. Mevki bazında bakıldığında, Bulanık ilçesindeki işletmelerin \%89.9'u ve Malazgirt'teki işletmelerin ise \%65.9'u kombine tipindedir (Çizelge 4). Süt tipi işletmelerin dağılımına bakıldığında, Korkut ilçesindeki işletmelerin tamamının, 
Varto'dakilerin \%92.9'unun ve Merkez'dekilerin \%72.2'sinin süt tipinde olduğu tespit edilmiştir.

Böylece ilçelerin işletme bazında bir karakter oluşturduğu tespit edilmiştir.
Köseman ve Şeker (2016), Malatya ilinde yaptığı çalışmasında işletmelerin \%35.2'sinin kombine üretim yaptığını, sadece süt üretimi yapan işletmelerin oranının \%5.6 olduğunu bildirmiştir.

Çizelge 4. Türkvet'e kayıt, işletme özelliği ve kayıt tutma durumunun mevkiye göre dağılımı

\begin{tabular}{|c|c|c|c|c|c|c|c|c|c|c|}
\hline \multirow[b]{2}{*}{ Mevki } & & \multicolumn{2}{|c|}{ Türkvete kayıt } & \multirow[b]{2}{*}{ Toplam } & \multicolumn{2}{|c|}{ Kayit tutma** } & \multirow[b]{2}{*}{ Toplam } & \multicolumn{2}{|c|}{ İşletme özelliği** } & \multirow[b]{2}{*}{ Toplam } \\
\hline & & Evet & Hayır & & Evet & Hayır & & Süt & Kombine & \\
\hline \multirow{2}{*}{ Merkez } & Adet & 51 & 3 & 54 & 20 & 34 & 54 & 39 & 15 & 54 \\
\hline & $\%$ & 94.4 & 5.6 & 100 & 37 & 63 & 100 & 72.2 & 27.8 & 100 \\
\hline \multirow{2}{*}{ Malazgirt } & Adet & 71 & 11 & 82 & 41 & 41 & 82 & 28 & 54 & 82 \\
\hline & $\%$ & 86.6 & 13.4 & 100 & 50 & 50 & 100 & 34.1 & 65.9 & 100 \\
\hline \multirow{2}{*}{ Bulanık } & Adet & 100 & 9 & 109 & 63 & 42 & 105 & 11 & 98 & 109 \\
\hline & $\%$ & 91.7 & 8.3 & 100 & 60 & 40 & 100 & 10.1 & 89.9 & 100 \\
\hline \multirow{2}{*}{ Hasköy } & Adet & 19 & 2 & 21 & 16 & 5 & 21 & 14 & 7 & 21 \\
\hline & $\%$ & 90.5 & 9.5 & 100 & 76.2 & 23.8 & 100 & 66.7 & 33.3 & 100 \\
\hline \multirow{2}{*}{ Korkut } & Adet & 22 & 2 & 24 & 23 & 1 & 24 & 24 & 0 & 24 \\
\hline & $\%$ & 91.7 & 8.3 & 100 & 95.8 & 4.2 & 100 & 100 & 0 & 100 \\
\hline \multirow{2}{*}{ Varto } & Adet & 49 & 7 & 56 & 30 & 24 & 54 & 52 & 4 & 56 \\
\hline & $\%$ & 87.5 & 12.5 & 100 & 55.6 & 44.4 & 100 & 92.9 & 7.1 & 100 \\
\hline \multirow{2}{*}{ Toplam } & Adet & 312 & 34 & 346 & 193 & 147 & 340 & 168 & 178 & 346 \\
\hline & $\%$ & 90.2 & 9.8 & 100 & 56.8 & 43.2 & 100 & 48.6 & 51.4 & 100 \\
\hline
\end{tabular}

$* * \mathrm{p}<0.01$

İşletmecilerin \%76.3'ü Muş ilinin süt sı̆̆ırcılı̆̆ına uygun olduğunu onaylamaktadır. İlçelerde ise Merkez, Korkut, Varto ilçelerindeki işletmelerin tamamına yakını ve Hasköy'deki işletmelerin tamamı ilin süt sığırcılığına uygun olduğunu belirtmişlerdir. İlin süt sığırcılığına uygun olmadığını belirten işletmecilerin en yüksek oranı Malazgirt (\%42.7) ve Bulanık ilçelerinde (\%34) bulunmuştur (Çizelge 5). Genel olarak, Muş ilinin süt sığırcılığı için uygun olmadığını belirten işletmecilerin \%58.8'i neden olarak "yem-ot pahalı/mera az" şeklinde belirtirken, bunu \%22.5 ile iklim uygun değil ve \%12.5 ile "işçi pahalı/ hayvan ucuz" seçenekleri izlemiştir. Varto'daki işletmelerin ilin süt sığırcılığı için uygun olmadığına neden olarak $\% 50$ 'sinin pazarlama ve \%50'sinin “yem-ot pahalı/mera az" demeleri dikkat çekici bulunmuştur. Bulanık ilçesindeki işletmelerde ilin süt sığırcılı̆̆ına uygun olmadığını belirlemede yem ve otun pahalı olması ile meraların az olması önemli (\%74.3) bir etken olarak tespit edilmiştir. Irkı neden olarak belirten tek ilçe Bulanık olmuştur. Bu durumun, Bulanık'taki işletmelerde kültür ırkının az bulunması, yoğunluğun ise yerli ve melez irktan oluşmasından kaynaklandığı düşünülmektedir.

Çizelge 5. Muş ilinin süt sı̆̆ırcılı̆̆ı için uygunluğunun mevkiye göre dağılımı

\begin{tabular}{|c|c|c|c|c|c|c|c|c|c|c|}
\hline \multirow[b]{2}{*}{ Mevki } & & \multicolumn{2}{|c|}{$\begin{array}{l}\text { Süt siğircılığına } \\
\text { uygunluk** }\end{array}$} & \multirow{2}{*}{ Toplam } & \multicolumn{5}{|c|}{ Hayır ise nedeni** } & \multirow[b]{2}{*}{ Toplam } \\
\hline & & Evet & Hayır & & Pazarlama & $\begin{array}{c}\text { Yem-ot pahalı/ } \\
\text { mera az }\end{array}$ & $\begin{array}{l}\text { İşçi pahalı/ } \\
\text { hayvan ucuz }\end{array}$ & İklim & $\begin{array}{l}\text { Irk } \\
\text { kötü }\end{array}$ & \\
\hline \multirow[t]{2}{*}{ Merkez } & Adet & 46 & 6 & 52 & 0 & 3 & 0 & 3 & 0 & 6 \\
\hline & $\%$ & 88.5 & 11.5 & 100.0 & 0.0 & 50.0 & 0.0 & 50.0 & 0.0 & 100.0 \\
\hline \multirow[t]{2}{*}{ Malazgirt } & Adet & 47 & 35 & 82 & 0 & 26 & 1 & 8 & 0 & 35 \\
\hline & $\%$ & 57.3 & 42.7 & 100.0 & 0.0 & 74.3 & 2.9 & 22.9 & 0.0 & 100.0 \\
\hline \multirow[t]{2}{*}{ Bulanık } & Adet & 70 & 36 & 106 & 4 & 17 & 9 & 6 & 8 & 36 \\
\hline & $\%$ & 66.0 & 34.0 & 100.0 & 11.1 & 47.2 & 25.0 & 16.7 & 22.2 & 100.0 \\
\hline \multirow[t]{2}{*}{ Hasköy } & Adet & 19 & 0 & 19 & - & - & - & - & - & - \\
\hline & $\%$ & 100.0 & 0.0 & 100.0 & - & - & - & - & - & - \\
\hline \multirow[t]{2}{*}{ Korkut } & Adet & 23 & 1 & 24 & 0 & 0 & 0 & 1 & 0 & 1 \\
\hline & $\%$ & 95.8 & 4.2 & 100.0 & 0.0 & 0.0 & 0.0 & 100.0 & 0.0 & 100.0 \\
\hline \multirow[t]{2}{*}{ Varto } & Adet & 52 & 2 & 54 & 1 & 1 & 0 & 0 & 0 & 2 \\
\hline & $\%$ & 96.3 & 3.7 & 100.0 & 50.0 & 50.0 & 0.0 & 0.0 & 0.0 & 100.0 \\
\hline \multirow[t]{2}{*}{ Toplam } & Adet & 257 & 80 & 337 & 5 & 47 & 10 & 18 & 8 & 80 \\
\hline & $\%$ & 76.3 & 23.7 & 100.0 & 6.2 & 58.8 & 12.5 & 22.5 & 10.0 & 100.0 \\
\hline
\end{tabular}

$* * p<0.01$ 
Diğer ilçelerdeki işletmecilerin yetiştirdikleri sığır ırklarından genel olarak memnun oldukları düşünülmektedir.

İşletmelerde en fazla \%38.4 oranıyla melez genotip yer alırken, bunu \%24 oranıla "yerli+melez" rrklar izlemektedir. Melez genotipin yoğun olarak yetiştirildiği işletmeler ise Merkez (\%54) ve Varto (\%69.6) ilçelerinde yer almaktadır. Sadece kültür ırkı bulunan işletmelerin oranı \%7.5 olup, en fazla kültür rrkı bulunduran işletmeler Korkut ve Hasköy ilçelerinde yer almaktadır (Çizelge 6). İşletmelerde yetiştirilen melez genotipler içerisinde en fazla Simental melezinin olduğu ve bunu Esmer melezlerinin izlediği tespit edilmiştir. Buna göre, işletmelerde melez genotipler tercih edilirken, melezler içerisinde de Simental ve Esmer ırkı melezler daha çok tercih edilmektedir. Simental melezi oranı Korkut ilçesinde \%90 ve Varto'da \%67.3 olarak tespit edilmiştir (Çizelge 7). Bakan ve Aydın (2016) Ağrı ilinde yaptığı çalışmasında, işletmelerde daha çok kültür ırkının bulunduğunu ve yerli ırkların oranının \%11.6 olduğunu tespit etmiştir. Aynı araştırmacı o bölgede kültür ırkları içerisinde Esmer (\%67.28) irkın daha yaygın olduğunu bildirmiştir. Tugay ve Bakır (2008) Giresun ilindeki işletmelerde \%71.1 oranında melez, \%23.6 oranında yerli ve \%5.3 oranında kültür ırkının bulunduğunu tespit etmiştir.

İşletmelerde görülen sorunlar, yemin pahalı olması, destek priminin az olması, pazarlama imkânlarının yetersiz olması, eğitim durumunun yetersiz olması, veteriner hizmetlerinin yetersiz olması, kaba yem üretiminin (temininin) yetersiz olması, kredilerin yetersiz olması şeklinde sıralanmaktadır.

İşletmelerde görülen sorunlar frekans değerlerine göre en çok karşılaşılan iki sorun; yemin pahalı olması (\%81.2) ve hayvancılığa uygulanan desteğin az olması (\%52) şeklinde bulunmuştur.

Çizelge 6. İşletmelerde bulunan mevcut ırkın mevkiye göre dağılımı

\begin{tabular}{|c|c|c|c|c|c|c|c|c|}
\hline \multirow{2}{*}{ Mevki } & & \multicolumn{6}{|c|}{ Mevcut irk** } & \multirow{2}{*}{ Toplam } \\
\hline & & Yerli & Kültür & Melez & Yerli+melez & Kültür+melez & Yerli+kültür+melez & \\
\hline \multirow{2}{*}{ Merkez } & Adet & 2 & 2 & 27 & 9 & 8 & 2 & 50 \\
\hline & $\%$ & 4.0 & 4.0 & 54.0 & 18.0 & 16.0 & 4.0 & 100.0 \\
\hline \multirow{2}{*}{ Malazgirt } & Adet & 12 & 0 & 33 & 9 & 0 & 26 & 80 \\
\hline & $\%$ & 15.0 & 0.0 & 41.3 & 11.3 & 0.0 & 32.5 & 100.0 \\
\hline \multirow{2}{*}{ Bulanık } & Adet & 9 & 1 & 17 & 55 & 5 & 19 & 106 \\
\hline & $\%$ & 8.5 & 0.9 & 16.0 & 51.9 & 4.7 & 17.9 & 100.0 \\
\hline \multirow{2}{*}{ Hasköy } & Adet & 1 & 7 & 7 & 0 & 0 & 2 & 17 \\
\hline & $\%$ & 5.9 & 41.2 & 41.2 & 0.0 & 0.0 & 11.8 & 100.0 \\
\hline \multirow{2}{*}{ Korkut } & Adet & 0 & 13 & 5 & 0 & 5 & 1 & 24 \\
\hline & $\%$ & 0.0 & 54.2 & 20.8 & 0.0 & 20.8 & 4.2 & 100.0 \\
\hline \multirow{2}{*}{ Varto } & Adet & 5 & 2 & 39 & 7 & 3 & 0 & 56 \\
\hline & $\%$ & 8.9 & 3.6 & 69.6 & 12.5 & 5.4 & 0.0 & 100.0 \\
\hline \multirow{2}{*}{ Toplam } & Adet & 29 & 25 & 128 & 80 & 21 & 50 & 333 \\
\hline & $\%$ & 8.7 & 7.5 & 38.4 & 24.0 & 6.3 & 15.0 & 100.0 \\
\hline
\end{tabular}

$* * \mathrm{p}<0.01$

Çizelge 7. İşletmelerde bulunan melez genotiplerin mevkiye göre dağılımı

\begin{tabular}{|c|c|c|c|c|c|c|c|}
\hline \multirow[b]{2}{*}{ Mevki } & & \multicolumn{5}{|c|}{ Melez ırk** } & \multirow[b]{2}{*}{ Toplam } \\
\hline & & $\begin{array}{l}\text { Esmer } \\
\text { melezi }\end{array}$ & $\begin{array}{c}\text { Simental } \\
\text { melezi }\end{array}$ & $\begin{array}{c}\text { Simental-Esmer } \\
\text { melezi }\end{array}$ & Alaca melezi & $\begin{array}{c}\text { Karışık } \\
\text { melez }\end{array}$ & \\
\hline \multirow{2}{*}{ Merkez } & Adet & 10 & 19 & 14 & 0 & 2 & 45 \\
\hline & $\%$ & 22.2 & 42.2 & 31.1 & 0.0 & 4.4 & 100.0 \\
\hline \multirow{2}{*}{ Malazgirt } & Adet & 14 & 17 & 20 & 0 & 16 & 67 \\
\hline & $\%$ & 20.9 & 25.4 & 29.9 & 0.0 & 23.9 & 100.0 \\
\hline \multirow{2}{*}{ Bulanık } & Adet & 19 & 30 & 40 & 1 & 6 & 96 \\
\hline & $\%$ & 19.8 & 31.3 & 41.7 & 1.0 & 6.3 & 100.0 \\
\hline \multirow{2}{*}{ Hasköy } & Adet & 2 & 3 & 1 & 1 & 1 & 8 \\
\hline & $\%$ & 25.0 & 37.5 & 12.5 & 12.5 & 12.5 & 100.0 \\
\hline \multirow{2}{*}{ Korkut } & Adet & 1 & 9 & 0 & 0 & 0 & 10 \\
\hline & $\%$ & 10.0 & 90.0 & 0.0 & 0.0 & 0.0 & 100.0 \\
\hline \multirow{2}{*}{ Varto } & Adet & 6 & 33 & 9 & 1 & 0 & 49 \\
\hline & $\%$ & 12.2 & 67.3 & 18.4 & 2.0 & 0.0 & 100.0 \\
\hline \multirow{2}{*}{ Toplam } & Adet & 52 & 111 & 84 & 3 & 25 & 275 \\
\hline & $\%$ & 18.9 & 40.4 & 30.5 & 1.1 & 9.1 & 100.0 \\
\hline
\end{tabular}


Ayrıca, işletmelerde karşılaşılan sorunlar; yemin pahalı olması ile bu faktörün pazar, destek primi ve kredinin yetersizliği faktörleri ile çeşitli kombinasyonlarından oluşmaktadır (Çizelge 8). İşletmelerde en çok karşılaşılan sorunlar kombinasyonunun ilkini, yemin pahalı olması temelinde diğer sorunların tekli olarak eklenmeleriyle oluşan "yem pahalı+/destek az/pazar/kredi/ eğitim/ veteriner hizmeti/ kaba yem" (\%20.2) faktörü oluşturmakta iken, bunu "yem pahalı+destek az+pazar" temelinde "yem pahall+ destek az+pazar+/kredi/ eğitim/veteriner hizmeti/kaba yem" (\%12.8) faktörü izlemiştir. Mevki bazında sorunlara bakıldığında, ilçelerde ilk sırada yer alan sorunlar, Malazgirt'te yemin pahalı olması (\%33,3), Hasköy'de pazarlama (\%26.3), Korkut'ta "yem pahall+/destek az/pazar/kredi/eğitim/ veteriner hizmeti/kaba yem", Varto'da "yem pahalı+destek az" kombinasyonları yer almaktadır. Eğitim (bilgi) eksikliği sorunu bazı kombinasyonlarda yer almakla birlikte, tek başına eğitimi sorun olarak belirten işletmelere ait oran sadece \%1.5 olarak bulunmuştur. İşletmecilerin eğitim sorununun ve bu konuda beklentilerinin az olmasinin sebebinin diğer temel sorunların eksikliğinden kaynaklandığ̣ düşünülmektedir. Yani işletme sahipleri bütün sorunların sebebinin yem fiyatlarının yüksek olması, veterinerlik hizmetlerinin pahalı olması ve pazarlama sorunlarından kaynaklandığını düşündüğünden dolayı eğitime ihtiyacının olmadığını bildirmektedir. Ancak eğitimin verilmesi gereken, özellikle kayıt tutma ve mera kullanımı konusunda büyük sıkıntıların olduğu görülmektedir.

İşletmelerde görülen beklentiler, frekans değerlerine göre incelendiğinde, anket yapılan işletmelerde frekans değerlerine göre en çok talep edilen iki beklenti destek primlerinin artırılması (\%67.3) ve damızlık hayvan temininin sağlanması (\%48.6) olmuştur. Ayrıca, Çizelge 8'de de görüldüğü gibi yemin pahalı olması tekli sorunlar içerisinde \%18.2'lik oranıyla önemli bir ağırlık oluştururken, kombine sorunların oranlarına yakın değere sahip olması da sorunlar içerisinde önemli bir yer tutmaktadır. Beklentilerde sorunlar gibi tekli ve çoklu kombinasyonlardan oluşmaktadır. Destek priminin yer aldiğgl, "destek primi+/ kredi/veteriner hizmeti" şeklinde olan ve daha çok maddi beklentiyi içeren bu kombinasyon \%14 oranıla en fazla belirtilen seçenek olmuştur.

İşletmecilerin verimi artırmak ve karlı üretim yapmak için, yetiştiricilik bilgisi istemeleri hem tekli hem de çoklu kombinasyonlu seçeneklerde yer almıştır. Frekans değerlerine göre, ilçelerde en fazla beklenti \%67.3 oranıyla destek priminin artırılması olmuştur. Bunu sirasiyla, damızlık hayvan temini (\%48.6), uygun kredi sağlanması (\%35.8), veteriner hizmetinin daha iyi verilmesi (\%31.2) izlemektedir. Genel olarak bakıldığında işletmelerin en fazla maddi destek beklenti içinde oldukları, yetiştiricilikle ilgili teknik bilgi isteyen işletmecilerin oranının sadece \%24 olması dikkat çekici bulunmuştur. İlçe bazında incelendiğinde öne çıkan beklentiler; Merkez'deki işletmelerde kredi, Malazgirt ve Hasköy'de damızlık hayvan, Bulanık ve Varto'da destek primi şeklindedir. Korkut ilçesinde ise "damılık+/teknik bilgi/destek primi”nden oluşan beklenti kombinasyonunda yetiştiricilik bilgisinin yer alması diğer ilçelerden farklılık oluşturmaktadır. Diğer ilçelerde genellikle maddi beklenti yoğunlukta iken, Korkut ilçesinde yetiştiricilikle ilgili teknik bilgi talebinin yer alması dikkat çekici bulunmuştur (Çizelge 9). Konya'da teknik bilgi alan üreticilerin \% 29.05'inin Tarım il ve ilçe Müdürlüklerinden, \%21.62'sinin özel veterinerlerden, \%18.92'sinin tarım teşkilatı ve özel veterinerlerden, \%1.35'inin üniversiteden, geriye kalan \% 29'luk kısmın ise basın ve diğer kaynaklardan teknik bilgileri aldıkları tespit edilmiştir (Akkuş, 2009).

Diler ve ark. (2017) Narman İlçesi'ndeki sığır yetiştiricilerinin \%59'unun teknik bilgi desteği alma gereksinimi duydukları, ancak \%41'lik bir kesimin hayvancılıkla ilgili teknik bilgilerini yenileme ve geliştirme ihtiyacı duymadıkları bildirmektedir. Ayrıca, bilgi desteği alan yetiştiriciler ise çoğunlukla (\%31) Veteriner Fakültesini tercih etmişlerdir. Benzer şekilde Ünalan ve ark. (2013) Niğde İlinde bilgi desteği alanların oranını \%66 olarak bildirirken, Koçyiğit ve ark. (2015) yetiştiricilerin \%83'ünün teknik bilgi desteği alma gereksinimi duymadıklarını, teknik bilgi desteği alanların ise \%58 oranında birlikleri tercih ettiklerini belirtmişlerdir.

Ağrı ilinde yapılan çalışmada işletmelerin başlıca sorunları hastalıklar (\%49.58), pazar (\%48.74) ve süt fiyatının düşük olması (1.68) olarak belirtilmiştir (Bakan ve Aydın, 2016). Köseman ve Şeker (2016) çalışmasında işletmecilerin beklentilerinin pazarlama desteği (\%32.7), kredi desteği (\%29.9), bilgi desteği (\%15.5), veterinerlik hizmeti desteği (\%14.4) ve damızlık temini desteği (\%7.5) şeklinde tespit etmiştir. Şeker ve ark. (2012) Muş ilinde yapmış olduğu çalışmasında işletmecilerin öncelikli sorunlarının yem ve yem maddelerinin pahalı olması $(\% 48.7)$ ve sığırcılığın karlı olmadığı (\%28.2) seçeneklerinden oluştuğunu, öncelikli beklentilerinin ise kredi desteği (\%42.7) ve veterinerlik hizmeti (\%29.1) olduğunu bildirmiştir. Boz (2013) Doğu Akdeniz Bölgesi’nde yaptığı çalışmada işletmecilerin en önemli sorunlarının yem fiyatlarının yüksek ve hayvancılığa verilen desteklemelerin az olduğunu belirtmiştir.

\section{SONUÇ}

Bu çalışmayla Muş ili ve ilçelerinde süt sığırcılığg işletmelerinin mevcut teknik ve yapısal özellikleri ortaya konulmuştur. 
Cizelge 8. İşletmelerde karşılaşılan sorunların mevkiye göre dağılımı

\begin{tabular}{|c|c|c|c|c|c|c|c|c|c|c|c|c|c|c|c|c|c|}
\hline \multirow[b]{2}{*}{ Mevki } & \multicolumn{16}{|c|}{ Sorunlar** } & \multirow[b]{2}{*}{ Toplam } \\
\hline & & $\begin{array}{c}\text { Yem } \\
\text { pahalı }\end{array}$ & $\begin{array}{c}\text { Destek } \\
\text { primi } \\
\text { az } \\
\end{array}$ & \multicolumn{2}{|c|}{ Pazarlama } & Eğitim & $\begin{array}{c}\text { Yem } \\
\text { pahalı+ } \\
\text { destek az }\end{array}$ & $\begin{array}{l}\text { Yem pahalı+ } \\
\text { kredi+ vet. } \\
\text { hizmeti }\end{array}$ & \multicolumn{2}{|c|}{$\begin{array}{c}\text { Yem pahalı+ } \\
\text { /pazar/eğitim } \\
\text { /kaba yem }\end{array}$} & \multicolumn{2}{|c|}{$\begin{array}{c}\text { Yem pahalı+ } \\
\text { destek az }+/ \\
\text { pazar/vet. hizmeti }\end{array}$} & \multicolumn{2}{|c|}{$\begin{array}{c}\text { Yem pah+des. az } \\
\text { + pazar+/kredi/ } \\
\text { /vet. hiz./kaba yem }\end{array}$} & $\begin{array}{c}\text { Yem pahalı+/ destek/ } \\
\text { kredi/ eğitim /vet. } \\
\text { hizmeti/ kaba yem }\end{array}$ & Diğerleri & \\
\hline & Adet & 2 & 5 & \multicolumn{2}{|c|}{5} & 0 & 2 & \multicolumn{3}{|l|}{2} & \multicolumn{2}{|c|}{6} & \multicolumn{2}{|c|}{9} & 17 & 5 & 53 \\
\hline \multirow[t]{2}{*}{ Merkez } & $\%$ & 3.8 & 9.4 & \multicolumn{2}{|c|}{9.4} & 0 & 3.8 & \multirow{2}{*}{\multicolumn{3}{|c|}{$\begin{array}{l}3.8 \\
2\end{array}$}} & \multicolumn{2}{|c|}{11.3} & \multicolumn{2}{|r|}{17} & 32.1 & 9.4 & 100 \\
\hline & Adet & 27 & 0 & \multicolumn{2}{|c|}{0} & 1 & 2 & & & & \multicolumn{2}{|c|}{4} & \multicolumn{2}{|r|}{9} & 17 & 6 & 81 \\
\hline Malazgirt & $\%$ & 33.3 & 0 & & 0 & 1.2 & 2.5 & \multicolumn{3}{|l|}{2.5} & \multicolumn{2}{|c|}{4.9} & & 11.1 & 21 & 7.4 & 100 \\
\hline & Adet & 14 & 4 & & 0 & 4 & 11 & 11 & & & 8 & & & 9 & 16 & 9 & 104 \\
\hline Bulanık & $\%$ & 13.5 & 3.8 & & 0 & 3.8 & 10.6 & 10.6 & & 7.3 & 7. & & & 8.7 & 15.4 & 8.7 & 100 \\
\hline & Adet & 4 & 1 & & 5 & 0 & 1 & 1 & & & 2 & & & 0 & 3 & 1 & 19 \\
\hline Hasköy & $\%$ & 21.1 & 5.3 & & 26.3 & 0 & 5.3 & 5.3 & & 3 & & .5 & & 0 & 15.8 & 5.3 & 100 \\
\hline & Adet & 1 & 0 & & 0 & 0 & 4 & 0 & & & 6 & & & 5 & 7 & 0 & 24 \\
\hline Korkut & $\%$ & 4.2 & 0 & & 0 & 0 & 16.7 & 0 & & 2 & & .0 & & 20.8 & 29.2 & 0.0 & 100 \\
\hline & Adet & 13 & 3 & & 0 & 0 & 14 & 0 & & & 3 & & & 9 & 8 & 0 & 55 \\
\hline Varto & $\%$ & 23.6 & 5.5 & & 0 & 0 & 25.5 & 0 & & 1 & 5 & & & 16.4 & 14.5 & 0 & 100 \\
\hline & Adet & 61 & 13 & & 10 & 5 & 34 & 16 & & & 2 & & & 41 & 68 & 26 & 336 \\
\hline Toplam & $\%$ & 18.2 & 3.9 & & 3 & 1.5 & 10.1 & 4.8 & & 1.3 & 8 & & & 12.8 & 20.2 & 7.7 & 100 \\
\hline $\begin{array}{l}\overline{* *} p<0.01 \\
\text { Cizelge } 9\end{array}$ & ${ }_{1}$ & 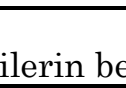 & 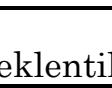 & & - & ye gi & lağılımı & & & & & & & & & & \\
\hline & & & & & & & & & Bekle & iler** & & & & & & & \\
\hline Mevki & & Kredi & $\begin{array}{r}\text { Veter } \\
\text { hizm }\end{array}$ & & $\begin{array}{r}\text { Damiz } \\
\text { hayv }\end{array}$ & $\begin{array}{ll}\text { zlık } & \\
\text { an } & \text { Tel }\end{array}$ & knik bilgi & $\begin{array}{c}\text { Destek } \\
\text { primi }\end{array}$ & $\begin{array}{l}\text { Xredi+ } \\
\text { diğer }\end{array}$ & $\begin{array}{r}\text { Damız } \\
\text { hizmet } \\
+ \text { kredi/ } \\
\end{array}$ & $\begin{array}{l}\text { zlik+vet. } \\
\text { i+ destek } \\
\text { tek. bilgi }\end{array}$ & $\begin{array}{r}\text { Damizlil } \\
+/ \mathrm{krec} \\
\text { hizl } \\
\end{array}$ & $\begin{array}{l}\mathrm{k}+\text { destek } \\
\text { di/ vet. } \\
\text { meti }\end{array}$ & $\begin{array}{c}\text { Damizlık+/te } \\
\text { knik bilgi } \\
\text { /destek } \\
\end{array}$ & $\begin{array}{c}\text { Destek prim+l } \\
\text { kredi/vet. } \\
\text { hizmeti }\end{array}$ & Diğerleri & Toplam \\
\hline & Adet & 10 & 2 & & 2 & & 0 & 6 & 6 & 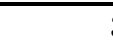 & 3 & 2 & 2 & 2 & 8 & 11 & 52 \\
\hline Merkez & $\%$ & 19.2 & 3.8 & & 3.8 & & 0 & 11.5 & 11.5 & & 5.8 & & 3.8 & 3.8 & 15.4 & 21.2 & 100 \\
\hline & Adet & 0 & 1 & & 19 & & 1 & 11 & 2 & & 16 & 6 & 6 & 10 & 11 & 4 & 81 \\
\hline Malazgirt & $\%$ & 0 & 1.2 & & 23. & & 1.2 & 13.6 & 2.5 & & 19.8 & & 7.4 & 12.3 & 13.6 & 4.9 & 100 \\
\hline & Adet & 1 & 3 & & 7 & & 4 & 24 & 8 & & 9 & & 13 & 8 & 19 & 8 & 104 \\
\hline Bulanık & $\%$ & 1 & 2.9 & & 6.7 & & 3.8 & 23.1 & 7.7 & & 8.7 & & 12.5 & 7.7 & 18.3 & 7.7 & 100 \\
\hline & Adet & 0 & 1 & & 6 & & 0 & 2 & 1 & & 0 & 1 & 1 & 4 & 2 & 2 & 19 \\
\hline Hasköy & $\%$ & 0 & 5.3 & & 31. & & 0 & 10.5 & 5.3 & & 0 & & 5.3 & 21.1 & 10.5 & 10.5 & 100 \\
\hline & Adet & 0 & 0 & & 2 & & 0 & 0 & 1 & & 0 & s & 9 & 11 & 1 & 0 & 24 \\
\hline Korkut & $\%$ & 0 & 0 & & 8.3 & & 0 & 0 & 4.2 & & 0 & & 37.5 & 45.8 & 4.2 & 0.0 & 100 \\
\hline & Adet & 2 & 0 & & 0 & & 0 & 25 & 3 & & 11 & 3 & 3 & 1 & 6 & 4 & 55 \\
\hline Varto & $\%$ & 3.6 & 0 & & 0 & & 0 & 45.5 & 5.5 & & 20 & & 5.5 & 1.8 & 10.9 & 7.3 & 100 \\
\hline & Adet & 13 & 7 & & 36 & & 5 & 68 & 21 & & 39 & & 28 & 31 & 47 & 40 & 335 \\
\hline Toplam & $\%$ & 3.9 & 2.1 & & 10. & & 1.5 & 20.3 & 6.3 & & 11.6 & & 8.4 & 9.3 & 14.0 & 11.9 & 100 \\
\hline
\end{tabular}


Muş ilinde büyükbaş süt sığırcılığı yapan yetiştiricilerin ortalama yaşının yüksek olduğu (44.21 yaş) ve buna bağlı olarak da tecrübesinin fazla olduğu (21.22 yıl) anlaşılmaktadır. İşletmecilerin yaş ortalamasının yüksek olması eğitim seviyelerinin de (ilkokul) düşük olmasını desteklemektedir. İşletme sahiplerinin çoğunluğunun kayıt tuttuğu ve hayvanlarının Türkvet'e kayıtlı olduğu belirlenmiştir. İşletme başına düşen hayvan sayısı ortalama olarak 37.54 baş olup bu hayvanların çoğunluğunun melez genotiplerden meydana geldiği ve melez genotipler içerisinde de Simental ırkı kanı taşıyanların daha yaygın olduğu görülmüştür. İşletme sahiplerinin damızlık hayvan ihtiyaçlarını genellikle kendi işletmelerinden sağladığı anlaşılmaktadır. İşletmecilerin çoğunluğu Muş ilinin süt sığırcılığı için uygun olduğunu bildirmiş, uygun değil diyen işletmeciler ise sebebini iklim olarak belirtmişlerdir. İşletmelerde karşılaşılan sorunların başında yem ve kaba yemin pahalı olmasının yanında desteğin az olması, veteriner hizmetinin pahalı olması, kaba yem sıkıntısı, eğitim ve kredi gibi sorunların da önemli olduğu anlaşılmıştır. İşletmelerin büyük bölümünün işletme sermayesi sıkıntısı çektikleri ve kendi öz varlıkları ile hayvancılık faaliyetini sürdürdükleri tespit edilmiştir. Bu nedenle, işletme sahiplerinin beklentileri arasinda ilk sirada destek priminin artırılması yer almış bunu kredi ve veteriner hizmetlerinin pahalı olması izlemiştir.

Muş ilinde büyükbaş süt sığırcılığı, işletmecilerin eğitim seviyesinin düşük olması ve teknik imkânların yetersizliği nedeniyle genellikle ekstansif olarak yapılmaktadır. Üretimi artırmak için işletmelerin teknik alt yapıları iyileştirilmeli ve verilecek desteklerle eğitim düzeyi yüksek teknik bilgiyle donanımlı gençlerin bu alana teşvik edilmesi sağlanmalıdır. Sığırcılık işletmelerinde kooperatif yapısında örgütlenme tipinin fazla yaygın olmadığı, mevcut kooperatiflerin de genel olarak işlevlerini yerine tam olarak getirmediği ve başarısız oldukları tespit edilmiştir. Yörede yetiştiricilerin çıkarlarını koruyacak yeterli ve etkin bir örgütlenme yapısının olmaması, başta elde edilen ürünlerin değerinde satılması için pazar sıkıntısı olmak üzere birçok konuda yetiştiricileri zor duruma düşürdüğü belirlenmiştir. Bu nedenle il genelinde yetiştiricilerin birlik ya da kooperatif şeklinde örgütlenmelerinin yaygınlaştırılması sağlanmalıdır.

\section{TEŞEKKÜR}

Bu çalışmanın yapılmasında emeği geçen Muş İl Tarım ve Orman Müdürlüğü personellerine teşekkür ederiz.

\section{KAYNAKLAR}

Akkuş Z, 2009. Konya İlindeki Süt Sığırcılığı İşletmelerinin Yapısal Özellikleri. SÜ. Fen Bil. Ens., Zootekni ABD, Doktora Tezi, 37s.
Aksoy A, Güler İO, Terin M 2014. Erzurum ili damızlık sığır yetiştiricileri birliğine üye olan ve olmayan üreticilerin belirli özellikler açısından karşılaştırılması. GOP Ziraat Fakültesi Dergisi. 31(3): $82-90$

Anonim 2018. Hayvancılık İstatistikleri. Türkiye İstatistik Kurumu. https://biruni.tuik. gov. tr /hayvancilikapp/hayvancilik.zul(Erişim tarihi: 09.03.2018).

Bakan Ö, Aydın R 2016. Ağrı İli Süt Sığırcılığg İşletmelerinin Sosyo-Ekonomik Özellikleri. Ziraat Fakültesi Dergisi, 47(2):113-122.

Bakır G 2002. Van İlindeki Özel Süt Sığırcılığı İşletmelerinde Tercih Edilen Kültür Irkları. YYÜ. Tarım Bilimleri Dergisi, 12(2):11-20.

Boz İ 2013. Doğu Akdeniz Bölgesi'nde Süt Siğırcılığı Yapan İşletmelerin Yapısı, Sorunları ve Çözüm Önerileri. KSÜ. Doğa Bilimleri Dergisi, 16(1):24-32.

CochranWG1977. Sampling techniques (3 ${ }^{\text {rd }}$ Edition). John Wiley\&Sons. New York. https://www. academia.edu/29684662/Cochran_1977_Sampling_ Techniques_Third_Edition. pdf. (Erişim: 14.01.2019).

Çoban O, Laçin E, Sabuncuoğlu N, Genç M 2013. Production and health parameters in cattle herds: A Survey from Eastern Turkey. Journal Animal and Plant Sciences, 23(6):1572-1577.

Diler A, Güler İO, Aydın R, Yanar M Koçyiğit R 2017. Erzurum ili Narman ilçesi sığırcılık işletmelerinde çiftlik yönetimi ve buzağı yetiştirme uygulamaları. Alınteri Ziraai Bilimler Dergisi, 32(1):39-45.

Düzgüneş O, Kesici T, Gürbüz F 1983. İstatistik Metodları I. Ankara Üniv. Ziraat Fak. Yay. 229.

Erdoğan HM, Çitil M, Güneş V, Saatci M 2004. Dairy cattle farming in Kars district, Turkey: I. Characteristics and production. Turkish J. Veterinary and Animal Sciences, 28(4):735-743.

Hozman S, Akçay H 2016. Sivas ili damızlık sığır yetiştiricileri birliğine üye süt sığırcılı̆̆ işletmelerinin bazı teknik ve ekonomik özellikleri. Tarım ekonomisi dergisi. 22(1): 57-65.

Ildız F 1999. Tokat ili merkez ilçesinde ithal sığır yetiştiren tarım işletmelerinin yapısı. Ankara Üniv. Fen Bil. Ens., Zootekni ABD, Yüksek Lisans Tezi, 77s.

Kaygisız A, Tümer R, Orhan H, Vanlı Y 2008. Kahramanmaraş Bölgesi Süt Siğırcılık İşletmelerinin Yapısal Özellikleri: 1. Yetiştirme Uygulamaları. SDÜ Ziraat Fakültesi Dergisi, 3 (2): 23-31.

Kaygisız A, Tümer R 2009. Kahramanmaraş İli Süt Sığırı İşletmelerinin Yapısal Özellikleri: 2. Barınak Özellikleri. KSÜ Doğa Bilimleri Derg., 12 (1): 40-47.

Kaygisız A, Tümer R, Orhan H, Vanlı Y 2010. Kahramanmaraş İli Süt Siğırcılık İşletmelerinin Yapısal Özellikleri: 4. İşletmecilerin Sosyal ve Kültürel Durumları. Atatürk Üniversitesi Ziraat Fakültesi Dergisi, 41 (1): 39-44. 
Koçyiğit R, Diler A, Yanar M, Güler O, Aydın R, Avcı M 2015. Erzurum İli Hınıs İlçesi sığırcılık işletmelerinin yapısal durumu: Çiftlik yönetimi ve buzağı yetiştirme uygulamaları. Iğdır Üniv. Fen Bilimleri Enstitüsü Dergisi, 5(4): 85-97.

Koçyiğit R, Diler, A Yanar, M Güler, O Aydın, R, Avcı M 2016. Süt sığırcılığı işletmelerinde hayvan sağlığ 1 , veteriner sağlık hizmetleri ve yetiştirici memnuniyeti: Erzurum ili Hınıs ilçesi örneği. Türk Tarım ve Doğa Bilimleri Dergisi. 3(1): 24-32.

Köseman A, Şeker İ 2016. Malatya İlinde Sığırcılık İşletmelerinin Mevcut Durumu: I. Yapisal Özellikler. Frrat Üniv. Sağllk Bilimleri Dergisi, 30(1): 5-12.

Önal AR, Özder M 2008. Edirne İli Damızlık Sı̆̆ır Yetiştiricileri Birliğine Üye İşletmelerin Yapısal Özellikleri. Tekirdağ Ziraat Fakültesi Dergisi, 5 (2):197-203.

Öztürk NN 2009. Mardin ilindeki süt sığırcılığı işletmelerinin yapısal özellikleri. SÜ. Fen Bil. Ens., Zootekni ABD, Yüksek Lisans Tezi, 65s.

Özyürek S, Koçyiğit R, Tüzemen N 2014. Erzincan İlinde süt sığırcılığ̣ yapan işletmelerin yapısal özellikleri: Çayırlı İlçesi örneği. Tekirdağ Ziraat Fakültesi Dergisi, 11(3):19-26.

Savaş S, Yenice G 2016. Rize İlinde Yapılan Süt Sığırcılığının Mevcut Durumunun Araştırılması. Atatürk Üniv. Veteriner Bilimleri Dergisi, 11(1):7483.
Soysal MI, Özder M 2004. Türkiye'de Süt Sığırcılığı Islah Çalışmaları. Hayvancılık Sempozyumu, 12-15 Eylül, Kırklareli.

Şahin K, Gürsoy AK 2016. Iğdır İli Süt Siğırcılığı İşletmelerinin Sosyo Ekonomik Yapısı. Nevşehir Bilim ve Teknoloji Dergisi, TARGID 5:118-129.

Şeker İ, Tasalı H, Güler H2012. Muş ilinde sığır yetiştiriciliği yapılan işletmelerin yapısal özellikleri. FÜ. Sağ. Bil. Vet. Derg., 26(1): 9-16.

Tilki M, Sarı M, Aydın E, Işıı S, Aksoy AR 2013. Kars ili sığır işletmelerinde barınakların mevcut durumu ve yetiştirici talepleri: I. Mevcut durum. Kafkas Üniv. Veteriner Fak. Derg. 19(1):109-116.

Tugay A, Bakır G 2008. Giresun yöresindeki sığırcılık işletmelerinde kullanılan yem çeşitleri ve hayvan besleme alışkanlıkları. Atatürk Üniv. Ziraat Fakültesi Dergisi,39(2): 231-239.

Tugay A, Bakır G 2010. Giresun yöresindeki süt sığırcılığg iş̧letmelerinin yapısal özellikleri. Atatürk Üniv. Ziraat FakültesiDergisi,40(1):37-47.

Ünalan A, Serbester U, Çınar M, Ceyhan A, Akyol E, Şekeroğlu A, Erdem T, Yılmaz S 2013. Niğde İli süt sığırcılığı işletmelerinin mevcut durumu, başlıca sorunları ve çözüm önerileri. Türk Tarım Gıda Bilim ve Teknoloji Dergisi, 1 (2): 67-72.

Yamane T 2006. Temel örnekleme yöntemleri. (Çeviri: Esin A, Bakır MA, Aydın C, Güzbüzsel E.) Literatür Yayınları: 53, İstanbul, 411. 